\title{
High-Flow vs. Low-Flow Nasal Cannula in Reducing Hypoxemic Events During Bronchoscopic Procedures: A Systematic Review and Meta-Analysis
}

\begin{abstract}
Fotios Sampsonas ${ }^{1 * t}$, Vasileios Karamouzos ${ }^{2 \dagger}$, Theodoros Karampitsakos ${ }^{1}$, Ourania Papaioannou ${ }^{1}$, Matthaios Katsaras ${ }^{1}$, Maria Lagadinou ${ }^{3}$, Eirini Zarkadi ${ }^{1}$, Elli Malakounidou ${ }^{1}$, Dimitrios Velissaris ${ }^{3}$, Grigorios Stratakos ${ }^{4}$ and Argyrios Tzouvelekis ${ }^{1}$

${ }^{1}$ Respiratory Medicine Department, University Hospital of Patras, Patras, Greece, ${ }^{2}$ Intensive Care Unit, University Hospital of Patras, Patras, Greece, ${ }^{3}$ Internal Medicine Department, University Hospital of Patras, Patras, Greece, ${ }^{4}$ Interventional Pulmonology Unit, First Respiratory Medicine Department of the National Kapodistrian University of Athens, Athens, Greece
\end{abstract}

Introduction: High-flow nasal cannula (HFNC) oxygenation method has been proven to be successful in oxygenation of patients with respiratory failure and has exhibited clinical superiority compared to low-flow nasal cannula (LFNC).

Rodrigo Torres-Castro, University of Chile, Chile

Reviewed by:

Jie Li,

Rush University, United States Felipe González-Seguel, Universidad del Desarrollo, Chile

*Correspondence:

Fotios Sampsonas

fsampsonas@upatras.gr

†These authors have contributed equally to this work

Specialty section:

This article was submitted to

Pulmonary Medicine

a section of the journal

Frontiers in Medicine

Received: 15 November 2021

Accepted: 25 January 2022

Published: 24 February 2022

Citation:

Sampsonas F, Karamouzos V

Karampitsakos T, Papaioannou O, Katsaras M, Lagadinou M, Zarkadi E, Malakounidou E, Velissaris $D$,

Stratakos G and Tzouvelekis A (2022)

High-Flow vs. Low-Flow Nasal

Cannula in Reducing Hypoxemic

Events During Bronchoscopic Procedures: A Systematic Review and Meta-Analysis. Front. Med. 9:815799.

doi: 10.3389/fmed.2022.815799
Methods: We performed a systematic review and meta-analysis to evaluate the potential favorable impact of HFNC oxygenation during bronchoscopy and related procedures like endobronchial ultrasound-transbronchial needle aspiration. Only randomized control trials (RCTs) were included in the meta-analysis.

Results: Six randomized control trials with 1,170 patients were included in this metaanalysis. Patients who underwent bronchoscopy with the use of high-flow nasal cannula experienced less hypoxemic events/desaturations, less procedural interruptions and pneumothoraxes compared to patients under low-flow nasal cannula treatment. This beneficial effect of HFNC in hypoxemic events was persistent 10 min after the end of procedure.

Conclusion: The high-flow nasal cannula (HFNC) oxygenation method could reduce hypoxemic events and related peri- and post-bronchoscopic complications.

Keywords: high-flow nasal cannula, low-flow nasal cannula, EBUS TBNA, hypoxemia, meta-analysis, bronchoscopy

\section{INTRODUCTION}

Oxygen supplementation therapy through high-flow nasal cannula (HFNC) has evolved over the last decade to an integral component of the management of patients with respiratory failure in multiple clinical scenarios (1). It is a noninvasive mechanical respiratory support modality developed to deliver a humidified and heated $\left(37^{\circ} \mathrm{C}\right)$ mixture of oxygen and air. Flow rates can vary from 10 to $80 \mathrm{~L} / \mathrm{min}$, where a continuous positive airway pressure (CPAP) effect can also develop $(1,2)$ by overcoming patient peak inspiratory flow rates, decreasing and washing out the anatomical dead space and, therefore, preventing alveolar collapse and decrease of dynamic compliance (3). Specially developed nasal prongs are used to deliver the oxygen flow, with inspired oxygen fraction 
$\left(\mathrm{FiO}_{2}\right)$ ranging from 0.21 to $1(1-4)$. HFNC can also successfully compensate increased inspiratory flow rates developed by a patient, providing a predictable and accurate $\mathrm{FiO} 2$ that can reach 1 (5). At the same time, it improves sputum expectoration by maintaining mucociliary clearance even at high flow rates due to humidification and heating of breathing-inspired air mixture (5) and finally reduces the work of breathing and preserves upper airway patency $(4,6)$.

Fiber optic bronchoscopy (FOB) is a diagnostic and interventional tool widely used in patients with a variety of respiratory diseases (7). Endobronchial ultrasound-guided transbronchial needle aspiration (EBUS-TBNA) has been also established as the core component for lung cancer diagnostic approach, by aspirating mediastinal lymph nodes and related pathologies (8). Periprocedural hypoxemia and respiratory failure development do not represent a rare complication of bronchoscopy, especially in sedated elderly patients with underlying comorbidities (9). Oxygen supplementation using a low-flow nasal cannula (LFNC) is advisable to be employed during the procedure in order to compensate for the development of hypoxemia and respiratory failure (7). Hypoxemia during bronchoscopy is associated with periprocedural complications like arrythmias and, thus, should be generally avoided and, if encountered, must be reverted (7).

In view of these advantages of HFNC over LFNC, and having in mind the increased need for accurate, safe, and prompt diagnosis of a plethora of lung diseases with the use of bronchoscopy/EBUS in patients with multiple comorbidities, we performed a systematic review and metaanalysis to address the possible favorable impact of HFNC administration in the development of respiratory failure during these bronchoscopic procedures.

\section{METHODS}

\section{Study Criteria}

Only randomized controlled trials (RCTs) were included in our study. Our study population comprised of hospitalized patients and outpatients who underwent diagnostic bronchoscopic procedures (FOB and/or EBUS-TBNA). Intensive care and pediatric patients were excluded. All studies comparing HFNC with LFNC during bronchoscopic procedures were included. Studies comparing different types of high-flow devices and/or different interfaces were excluded.

\section{Search Strategy and Article Selection}

The Preferred Reporting Items for Systematic Reviews and MetaAnalysis (PRISMA) statement (10) was used for this study. Two researchers (FS and VK) performed an independent thorough search of the PubMed/Medline, EMBASE, Web of Science, and Cochrane databases from inception to December 2021 using the keywords "high flow oxygen," "high flow nasal oxygen," "HFNC," "bronchoscopy," and "Endobronchial Ultrasound/EBUS." No publication date restrictions were applied, and only articles in English were included. After removing all duplicates, two researchers (FS and VK) independently reviewed all abstracts, and all eligible articles were retrieved for further assessment.

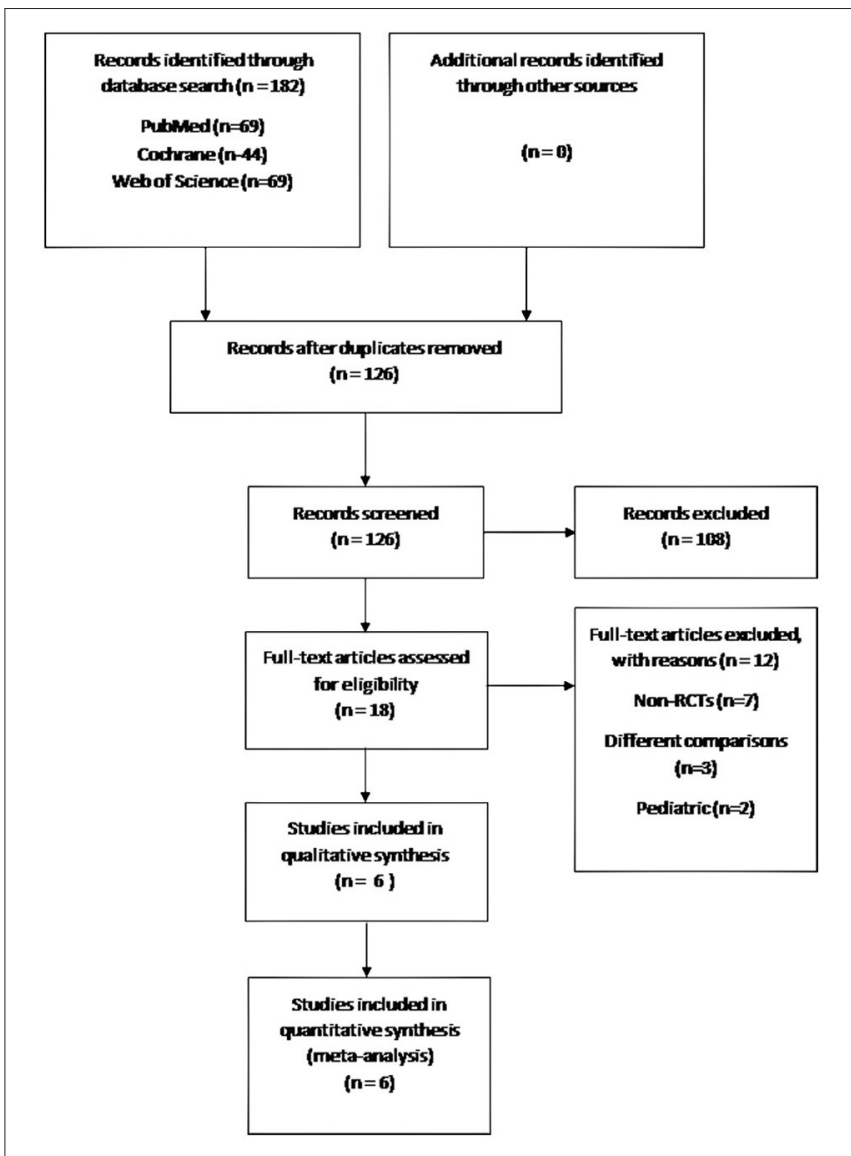

FIGURE 1 | Study flow chart.

Disagreements were resolved by consensus with a senior author (AT). The process of article selection is presented in the PRISMA flow chart (Figure 1).

\section{Data Extraction}

Data extraction was performed independently by two authors (FS and VK) while two other authors (TK and AT) examined the two data sets for discrepancies. The extracted data included first author name, year of publication, country, chronicity, study design, procedure type, inclusion/exclusion criteria, sample size, mean age, gender, exposure/control group, and outcome data. In the study of Douglas et al. (11), the authors decided to perform a per protocol analysis after reporting results of an intention-totreat analysis. We included in our study the more conservative intention-to-treat analysis results.

\section{Outcomes}

Our primary outcome was desaturation events, defined as an oxygen saturation $\left(\mathrm{SpO}_{2}\right)$ drop below $90 \%$ at least once during the bronchoscopic procedure. Secondary outcomes were the lowest value of $\mathrm{SpO}_{2}$ during the procedure, hypoxemia duration, procedure duration, partial pressure of carbon dioxide $\left(\mathrm{PCO}_{2}\right)$ at the end of the procedure, respiratory rate $(\mathrm{RR})$, heart rate $(\mathrm{HR})$, mean arterial pressure (MAP) and $\mathrm{SpO}_{2} 10 \mathrm{~min}$ after the end 
of the procedure. Furthermore, incidence of pneumothorax and procedural interruption were also examined.

\section{Quality Assessment}

Quality assessment was also carried out independently by two authors (FS and VK) using the Risk of Bias tool (RoB 2) for RCTs (12). The authors classified the included studies as low, moderate, or high/serious risk. Risk of bias visualization was performed in $\mathrm{R}$ using the Risk-of-bias VISualization (robvis) package (13).

\section{Statistical Analysis}

A pairwise meta-analysis was performed in $\mathrm{R}$ version 3.6.1 using the packages "meta" and "metafor." A random effects model was used for all outcomes. Risk ratio and mean difference were selected as the measure of effect for binary and continuous outcomes, respectively. $Q$ and $I^{2}$ statistics were used to explore and measure heterogeneity, respectively. $I^{2}=0-40 \%$ suggests not important heterogeneity, $I^{2}=30-60 \%$ suggests moderate heterogeneity, $I^{2}=50-90 \%$ suggests substantial heterogeneity, and $I^{2}=75-100 \%$ suggests considerable heterogeneity. In studies with data not normally distributed, the mean and standard deviation were estimated using sample size, median, and interquartile range (IQR) provided that skewness was acceptable $(14,15)$. Publication bias detection using a funnel plot was not carried out, since in our analysis we included $<10$ studies, and the test is not powered for such a small sample size.

\section{RESULTS}

\section{Study Characteristics}

Six studies were included in the qualitative assessment with a total of 1,170 patients $(11,16-20)$. All patients were outpatients and/or hospitalized patients but not intubated or patients treated in the intensive care unit. In three studies, patients underwent fiberoptic bronchoscopy (FOB) \pm bronchoalveolar lavage (BAL) or biopsy; and in three studies, EBUS-TBNA was performed. In four studies, intravenous sedation was administered and in two only topical sedation. All six studies were included in the quantitative analysis (11, 16-20). Study characteristics are summarized in Table $\mathbf{1}$.

\section{Quality Assessment}

For RCTs, we used the ROB 2 tool to evaluate the risk of bias in the included studies. Three studies were judged as studies with some concerns in the first domain. Two of them exhibited imbalances in baseline characteristics $(11,19)$, and in the third trial, age was not reported (16). The results are summarized in Figures 2, 3 .

\section{Incidence of Desaturation During Bronchoscopy}

All six studies measured the incidence of desaturation $\left(\mathrm{SpO}_{2}<\right.$ $90 \%$ at least once during the procedure) during bronchoscopy $(11,16-20)$. The incidence of desaturation was statistically lower in patients who received support with HFNC during bronchoscopic procedures $(\mathrm{RR}=0.3 ; 95 \% \mathrm{CI}=0.2,0.45 ; p<0.01$; $\left.I^{2}=31 \%\right)$ (Figure 4).

\section{Lowest $\mathrm{SpO}_{2}$ During the Procedure and Hypoxemia Duration}

Five trials measured the lowest $\mathrm{SpO}_{2}$ value during bronchoscopy $(11,16,17,19,20)$. Patients in the LFNC group had significantly lower $\mathrm{SpO}_{2}$ values than patients in the HFNC group in those receiving support with HFNC (MD $=6.18 ; 95 \% \mathrm{CI}=4.01,8.36$; $p<0.01 ; I^{2}=85 \%$ ) (Figure 5). Regarding hypoxemia duration, differences observed were not statistically significant. Two studies showed reduced hypoxemia duration when using $\operatorname{HFNC}(17,20)$, and one study showed reduced hypoxemia duration when using LFNC $\left(\mathrm{MD}=-52.6 ; 95 \% \mathrm{CI}=-178.03,72.83 ; p=0.41 ; I^{2}=\right.$ 97\%) (Figure 6).

\section{Bronchoscopic Duration and $\mathrm{PCO}_{2}$ at the End of the Procedure}

Three trials measured procedure duration $(17,18,20)$, and although the mean duration of bronchoscopy in the HFNC group was less than that in the LFNC group, the difference was not significant $\left(\mathrm{MD}=-1.18 ; 95 \% \mathrm{CI}=-2.81,0.45 ; p=0.16 ; I^{2}\right.$ $=69 \%)$ (Figure 7). Likewise, no difference was observed in two studies $(16,19)$ that measured $\mathrm{PCO}_{2}$ at the end of the procedure $\left(\mathrm{MD}=0.16 ; 95 \% \mathrm{CI}=-2.74,3.07 ; p=0.91 ; I^{2}=0 \%\right)$ (Figure 8).

\section{$\mathrm{SpO}_{2}$, Respiratory Frequency, Heart Rate, and Mean Arterial Pressure 10 min After the Procedure}

Two studies measured $\mathrm{SpO}_{2}$, heart rate (HR), respiratory frequency (RF), and mean arterial pressure (MAP) 10 min after the end of the procedure $(18,20)$. Mean $\mathrm{SpO}_{2}$ was significantly higher in the HFNC group ( $\mathrm{MD}=1.24 ; 95 \% \mathrm{CI}=0.89,1.59$; $p<0.01 ; I^{2}=0 \%$ ) (Figure 9). No difference was observed in RF (MD $=-0.54 ; 95 \% \mathrm{CI}=-1.51,0.44 ; p=0.28 ; I^{2}=77 \%$; Figure 10), $\mathrm{HR}\left(\mathrm{MD}=-2.5 ; 95 \% \mathrm{CI}=-6.29,1.3 ; p=0.2 ; I^{2}=\right.$ $59 \%$; Figure 11), and MAP (MD $=0.27 ; 95 \% \mathrm{CI}=-1.69,2.24 ; p$ $=0.79 ; I^{2}=0 \%$; Figure 12).

\section{Procedure Interruptions, Pneumothorax, and Intubation Incidence}

Data on procedure interruptions were available in three trials $(11,17,20)$. Bronchoscopy was less frequently interrupted in the HFNC group compared to the LFNC group ( RR $=0.38 ; 95 \%$ $\mathrm{CI}=0.27,0.53 ; p<0.01 ; I^{2}=0 \%$ ) (Figure 13). Pneumothorax incidence also differs significantly between the two groups and is more frequent in patients receiving support with LFNC (RR $=0.49 ; 95 \% \mathrm{CI}=0.25,0.97 ; p=0.04 ; I^{2}=0 \%$ ) (Figure 14). Finally, in both arms, intubation incidence was zero in two trials that measured this outcome $(16,19)$.

\section{DISCUSSION}

The main outcome of our study was that the implementation of HFNC during bronchoscopic procedures, including EBUS, can potentially reduce hypoxemic events compared to that of LFNC. This is of major clinical interest, since bronchoscopic procedures are usually time-consuming and require deep levels of sedation, and thus, more prone to cause desaturations (21). Moreover, 


\begin{tabular}{|c|c|c|c|c|c|c|c|c|c|c|c|c|}
\hline & First author & Type of study & $\begin{array}{l}\text { Country/ } \\
\text { Chronicity }\end{array}$ & $\begin{array}{l}\text { Procedure/ } \\
\text { Access route }\end{array}$ & $\begin{array}{l}\text { Inclusion } \\
\text { criteria }\end{array}$ & Exclusion criteria & $\begin{array}{l}\text { Sample } \\
\text { size (C/l) }\end{array}$ & $\begin{array}{l}\text { Age (C/I) / } \\
\text { F. gender } \\
\text { (C/I) }\end{array}$ & Outcomes & Sedation & $\begin{array}{l}\text { Control/ } \\
\text { Intervention } \\
\text { group }\end{array}$ & Main results \\
\hline \multirow[t]{3}{*}{1} & $\begin{array}{l}\text { Ben-Menachem } \\
\text { et al. (17) }\end{array}$ & $\mathrm{RCT}$ & Australia & $\begin{array}{l}\text { FOB with } \\
\text { transbronchial } \\
\text { lung biopsy }\end{array}$ & $\begin{array}{l}\text { Adult, } \\
\text { Transplant } \\
\text { recipients }\end{array}$ & $\begin{array}{l}<18 \text { years, non-lung } \\
\text { transplant patients, } \\
\text { cardiovascular or } \\
\text { respiratory failure, } \\
\text { reduced level of } \\
\text { consciousness, } \\
\text { pregnancy, significant } \\
\text { aspiration risk, need } \\
\text { for a laryngeal mask } \\
\text { airway or endotracheal } \\
\text { intubation, unable to } \\
\text { have sedation with } \\
\text { propofol or unsuitable } \\
\text { for HFNC such as } \\
\text { recent nasal surgery } \\
\text { or a base of skull } \\
\text { defect or fracture }\end{array}$ & 76 patients & $55.8 / 54.9$ & $\begin{array}{l}\text { Procedure duration, } \\
\text { Dose of Sedative } \\
\text { agents, Bispectral } \\
\text { Index, Satisfaction } \\
\text { score, Duration of } \\
\text { desaturation, } \\
\text { Pneumothorax }\end{array}$ & $\begin{array}{l}\text { Preprocedure: } \\
\text { Nebulized } 2 \% \\
\text { lidocaine and } \\
\text { midazolam } 1 \text { to } \\
3 \mathrm{mg} \text { i.v. } \\
\text { Procedure: } \\
\text { propofol and } \\
\text { alfentanil }\end{array}$ & $\begin{array}{l}\text { C: } 4-10 L \\
\text { LFNC }\end{array}$ & $\begin{array}{l}\text { The proportion } \\
\text { of patients with } \\
\text { desaturation, } \\
\text { SpO2< } 90 \% \text {, was } \\
\text { lower in the HFNO } \\
\text { group; } 16.2 \% \text { vs. } \\
69.2 \% \text { in the } \\
\text { LFNO group } \\
(\mathrm{P}<0.001) \text {, The } \\
\text { Duration of } \\
\text { desaturation was } \\
\text { Higher in LFNC, } \\
\text { Anesthetist was } \\
\text { more satisfied with } \\
\text { HFNC. }\end{array}$ \\
\hline & & & $\begin{array}{l}\text { May } 2018 \text { to May } \\
2019\end{array}$ & Oral & & & C:39 & C: 10 & & & $\begin{array}{l}\text { I: } 30-50 L \\
\text { HFNC }\end{array}$ & \\
\hline & & & & & & & |:37 & I: 15 & & & & \\
\hline \multirow[t]{3}{*}{2} & $\begin{array}{l}\text { Douglas et al. } \\
\text { (11) }\end{array}$ & $\mathrm{RCT}$ & Australia & EBUS & $\begin{array}{l}\text { Adult, able to } \\
\text { give informed } \\
\text { consent, } \\
\text { sedation } \\
\text { planned, and } \\
\text { English } \\
\text { speaking }\end{array}$ & $\begin{array}{l}<18 \text { years, unable to } \\
\text { consent, trachea } \\
\text { intubated or requiring } \\
\text { intubation for } \\
\text { procedure, pregnant, } \\
\text { active nasal bleeding, } \\
\text { or base of skull } \\
\text { fracture }\end{array}$ & 60 patients & $63.4 / 62.8$ & $\begin{array}{l}\text { Proportion of patients } \\
\text { experiencing } \\
\text { desaturation below } \\
90 \% \text {, oxygen } \\
\text { saturation, duration of } \\
\text { hypoxia, } \\
\text { end-procedure } \\
\text { end-tidal CO2, } \\
\text { satisfaction score, } \\
\text { number of } \\
\text { interruptions, } \\
\text { arrhythmia, myocardial } \\
\text { ischaemia and cardiac } \\
\text { arrest }\end{array}$ & $\begin{array}{l}\text { Preprocedural: } \\
\text { topical lidocaine } \\
2 \% \\
\text { Procedural: } \\
\text { midazolam, } \\
\text { opioids and/or } \\
\text { propofol }\end{array}$ & $\begin{array}{l}\text { C: } 10-15 \mathrm{~L} \\
\text { LFNC }\end{array}$ & $\begin{array}{l}\text { Spo2 }<90 \% \text { in } \\
\text { Intension to treat } \\
\text { analysis revealed } \\
\text { no difference }(4 / 30 \\
\text { vs. } 10 / 30) \text {. In the } \\
\text { Per protocol } \\
\text { analysis significant } \\
\text { difference } 4 / 31 \text { vs. } \\
10 / 29, \text { The } \mathrm{SpO}_{2} \\
\text { following } \\
\text { pre-oxygenation } \\
\text { was significantly } \\
\text { higher in the } \\
\text { HFNO The median } \\
\text { lowest } \mathrm{SpO} \mathrm{O}_{2} \\
\text { observed during } \\
\text { the procedure in } \\
\text { the HFNO group } \\
\text { was significantly } \\
\text { higher }\end{array}$ \\
\hline & & & $\begin{array}{l}14 \text { February } \\
2017-23 \text { May } \\
2017\end{array}$ & No information & & & C:30 & C: 11 & & & $\begin{array}{l}\text { I: } 30-70 \mathrm{LFO}_{2}: \\
100 \% \mathrm{HFNC}\end{array}$ & \\
\hline & & & & & & & 1:30 & l: 11 & & & & \\
\hline
\end{tabular}


TABLE 1 | Continued

\begin{tabular}{|c|c|c|c|c|c|c|c|c|c|c|c|c|}
\hline & First author & Type of study & $\begin{array}{l}\text { Country/ } \\
\text { Chronicity }\end{array}$ & $\begin{array}{l}\text { Procedure/ } \\
\text { Access route }\end{array}$ & $\begin{array}{l}\text { Inclusion } \\
\text { criteria }\end{array}$ & Exclusion criteria & $\begin{array}{l}\text { Sample } \\
\text { size (C/I) }\end{array}$ & $\begin{array}{l}\text { Age (C/I) / } \\
\text { F. gender } \\
\text { (C/I) }\end{array}$ & Outcomes & Sedation & $\begin{array}{l}\text { Control/ } \\
\text { Intervention } \\
\text { group }\end{array}$ & Main results \\
\hline \multirow[t]{3}{*}{3} & Irfan et al. (19) & $\mathrm{RCT}$ & UK & EBUS-TBNA & $\begin{array}{l}\text { Adult, } \\
\text { saturation } \\
\geq 90 \% \text { on air, } \\
\text { Being able to } \\
\text { breathe } \\
\text { spontaneously } \\
\text { throughout the } \\
\text { procedure }\end{array}$ & $\begin{array}{l}\text { Cardiorespiratory } \\
\text { failure, recent } \\
\text { myocardial infarction } \\
\text { within } 6 \text { wk, long-term } \\
\text { oxygen therapy, } \\
\text { tracheostomy, } \\
\text { noninvasive } \\
\text { ventilation, nasal or } \\
\text { nasopharyngeal } \\
\text { disease, inability to } \\
\text { give informed consent, } \\
\text { dementia, hepatic or } \\
\text { end-stage renal } \\
\text { disease, pregnancy }\end{array}$ & 40 Patients & $64.5 / 61.9$ & $\begin{array}{l}\text { Primary end-point: } \\
\text { drop in the oxygen } \\
\text { saturations from the } \\
\text { start of the procedure } \\
\text { Secondary } \\
\text { end-points: changes } \\
\text { in venous blood CO2 } \\
\text { lowest } \\
\text { oxygen saturation, } \\
\text { Changes in end tidal } \\
\text { CO2, requirement for } \\
\text { intubation, overall } \\
\text { experience on a visual } \\
\text { analog scale (VAS) }\end{array}$ & $\begin{array}{l}\text { Preprocedural: } \\
\text { local anesthesia } \\
\text { Procedural: } \\
\text { midazolam } \\
\text { and alfentanil } \\
\end{array}$ & C: LFNC & $\begin{array}{l}\text { Primary outcome: } \\
\text { Oxygen } \\
\text { desaturation } \\
\text { was statistically } \\
\text { significant with a } \\
\text { difference } \\
\text { of } 7.7 \text { percentage } \\
\text { points } \\
\text { Secondary } \\
\text { outcome: The } \\
\text { lowest oxygen } \\
\text { saturation was } \\
\text { also statistically } \\
\text { significant with a } \\
\text { difference of }-9.2 \text {. }\end{array}$ \\
\hline & & & No Information & No information & & & & $\begin{array}{l}\text { No } \\
\text { information }\end{array}$ & & & I: HFNC & \\
\hline & & & & & & & I: 20 & & & & & \\
\hline \multirow[t]{3}{*}{4} & $\begin{array}{l}\text { Longhini et al. } \\
\text { (16) }\end{array}$ & $\mathrm{RCT}$ & Italy & FOB with BAL & $\begin{array}{l}\text { Adult (aged } \\
\geq 18 \text { years), } \\
\text { outpatients }\end{array}$ & $\begin{array}{l}\text { life-threatening } \\
\text { arrhythmia, recent } \\
\text { myocardial infarction, } \\
\text { oxygen therapy or } \\
\text { home mechanical } \\
\text { ventilation, pulmonary } \\
\text { emphysema, history of } \\
\text { spontaneous } \\
\text { pneumothorax, recent } \\
\text { thoracic surgery, } \\
\text { presence of skin } \\
\text { lesions on the chest, } \\
\text { tracheostomy, chronic } \\
\text { elevation and/or } \\
\text { paralysis of a } \\
\text { hemidiaphragm, } \\
\text { inability to express an } \\
\text { informed consent, } \\
\text { consent withdrawal, } \\
\text { presence of } \\
\text { morbid obesity, } \\
\text { inclusion in other } \\
\text { research protocols. }\end{array}$ & 36 patients & $\begin{array}{l}\text { No } \\
\text { information }\end{array}$ & $\begin{array}{l}\mathrm{PaO} 2 \text { at the end of } \\
\text { FOB with } \mathrm{BAL} \text {, the } \\
\text { lowest } \\
\text { peripheral saturation } \\
\text { of oxygen (SpO2) and } \\
\text { the number of oxygen } \\
\text { desaturations, the } \\
\text { changes } \\
\text { of end-expiratory lung } \\
\text { impedance (EELI) } \\
\text { and tidal impedance } \\
\text { assessed by electrical } \\
\text { impedance } \\
\text { tomography (EIT), the } \\
\text { effects on diaphragm } \\
\text { function assessed } \\
\text { by ultrasound }\end{array}$ & $\begin{array}{l}\text { Preprocedural: } \\
\text { topical lidocaine } \\
2 \% \\
\text { Procedural: } \\
\text { topical lidocaine } \\
2 \%\end{array}$ & C: LFNC & $\begin{array}{l}10(56 \%) \text { patients } \\
\text { had one or more } \\
\text { episodes of } \\
\text { desaturation in the } \\
\text { LFNC group, while } \\
\text { only } 2 \text { patients } \\
\text { (11\%) in the HFNC } \\
\text { group }\end{array}$ \\
\hline & & & $\begin{array}{l}\text { September } 2019 \\
\text { to February } 2020\end{array}$ & Oral & & & C:18 & C: 6 & & & $\begin{array}{l}\text { I: HFNC } 60 \mathrm{~L} \\
\text { starting at } 0.21 \\
\text { FiO2 }\end{array}$ & \\
\hline & & & & & & & |:18 & I: 3 & & & & \\
\hline
\end{tabular}


TABLE 1 | Continued

\begin{tabular}{|c|c|c|c|c|c|c|c|c|c|c|c|c|}
\hline & First author & Type of study & $\begin{array}{l}\text { Country/ } \\
\text { Chronicity }\end{array}$ & $\begin{array}{l}\text { Procedure/ } \\
\text { Access route }\end{array}$ & $\begin{array}{l}\text { Inclusion } \\
\text { criteria }\end{array}$ & Exclusion criteria & $\begin{array}{l}\text { Sample } \\
\text { size (C/I) }\end{array}$ & $\begin{array}{l}\text { Age (C/I) / } \\
\text { F. gender } \\
\text { (C/I) }\end{array}$ & Outcomes & Sedation & $\begin{array}{l}\text { Control/ } \\
\text { Intervention } \\
\text { group }\end{array}$ & Main results \\
\hline \multirow[t]{3}{*}{5} & Ucar et al. (18) & $\mathrm{RCT}$ & Turkey & EBUS-TBNA & Adult patients & $\begin{array}{l}\text { Body mass index } \\
\text { (BMI) higher than } 30 \text {, } \\
\text { tracheostomy, nasal or } \\
\text { nasopharyngeal } \\
\text { disease, difficulty in } \\
\text { communicating, } \\
\text { pregnancy }\end{array}$ & $\begin{array}{l}170 \\
\text { patients }\end{array}$ & $57.8 / 57.5$ & $\begin{array}{l}\text { Desaturation from } \\
\text { baseline, Heart Rate. } \\
\text { Blood Pressure } \\
\text { immediate and 10' } \\
\text { after procedure, } \\
\text { patient self-reported } \\
\text { comfort }\end{array}$ & $\begin{array}{l}\text { Preprocedural: } \\
\text { topical lidocaine } \\
2 \% \\
\text { Procedural: } \\
\text { midazolam }\end{array}$ & $\begin{array}{l}\text { C: LFNC of } \\
\text { similar FiO2 }\end{array}$ & $\begin{array}{l}5(6 \%) \text { one or } \\
\text { more episodes of } \\
\text { desaturation in } \\
\text { HFNC, } 26(31 \%) \text { in } \\
\text { ST group }\end{array}$ \\
\hline & & & 2018-2019 & Oral & & & & C:55 & & & $\begin{array}{l}\text { I: HFNC FiO2 } \\
40 \% \text {, 35lt }\end{array}$ & \\
\hline & & & & & & & I: 85 & I: 56 & & & & \\
\hline \multirow[t]{3}{*}{6} & Wang et al. (20) & $\mathrm{RCT}$ & China & $\mathrm{FOB}+\mathrm{BA}$ & $\begin{array}{l}\text { Adult and } \\
\text { indication for } \\
\text { diagnostic } \\
\text { bronchoscopy }\end{array}$ & $\begin{array}{l}\mathrm{SpO} 2<90 \% \text { on room } \\
\text { air, platelet count }<60 \\
\times 10^{9} / \mathrm{L} \text {, and } \\
\text { nasopharyngeal } \\
\text { obstruction or } \\
\text { blockage }\end{array}$ & $\begin{array}{l}788 \\
\text { patients }\end{array}$ & $59 / 58$ & $\begin{array}{l}\text { The primary endpoint } \\
\text { was the proportion of } \\
\text { patients with a single } \\
\text { moment of SpO2 } \\
<90 \% \text {. The secondary } \\
\text { endpoint was the } \\
\text { duration of } \\
\text { Bronchoscopy. Other } \\
\text { endpoints were } \\
\text { durationof SpO2 < } \\
90 \% \text { and the } \\
\text { proportion of patients } \\
\text { with procedural } \\
\text { discontinuation }\end{array}$ & $\begin{array}{l}\text { Preprocedural: } \\
\text { topical lidocaine } \\
\text { 2\% Procedural: } \\
\text { topical lidocaine } \\
2 \%\end{array}$ & C: LFNC 6L & $\begin{array}{l}\text { The proportion of } \\
\text { patients with a } \\
\text { single moment of } \\
\mathrm{SpO} 2<90 \% \\
\text { during } \\
\text { bronchoscopy in } \\
\text { the HFNC group } \\
\text { was significantly } \\
\text { lower than that in } \\
\text { the LFNC. The } \\
\text { lowest SpO2 } \\
\text { during } \\
\text { bronchoscopy and } \\
5 \text { min after } \\
\text { bronchoscopy in } \\
\text { the HFNC group } \\
\text { was significantly } \\
\text { higher than that in } \\
\text { the LFNC group. }\end{array}$ \\
\hline & & & $\begin{array}{l}\text { November } 2015 \\
\text { to October } 2019\end{array}$ & Nasal & & & C: 396 & C: 174 & & & I: HFNC 50L & \\
\hline & & & & & & & I: 392 & I: 188 & & & & \\
\hline
\end{tabular}

RCT, randomized control trial, FOB, fiberoptic bronchoscopy, HFNC, High Flow Nasal Canula, LFNC, Low flow nasal canula, EBUS, Endobronchial Ultrasound, FiO ${ }_{2}$, fraction of inspired oxygen, SpO 2 , peripheral oxygen saturation. 


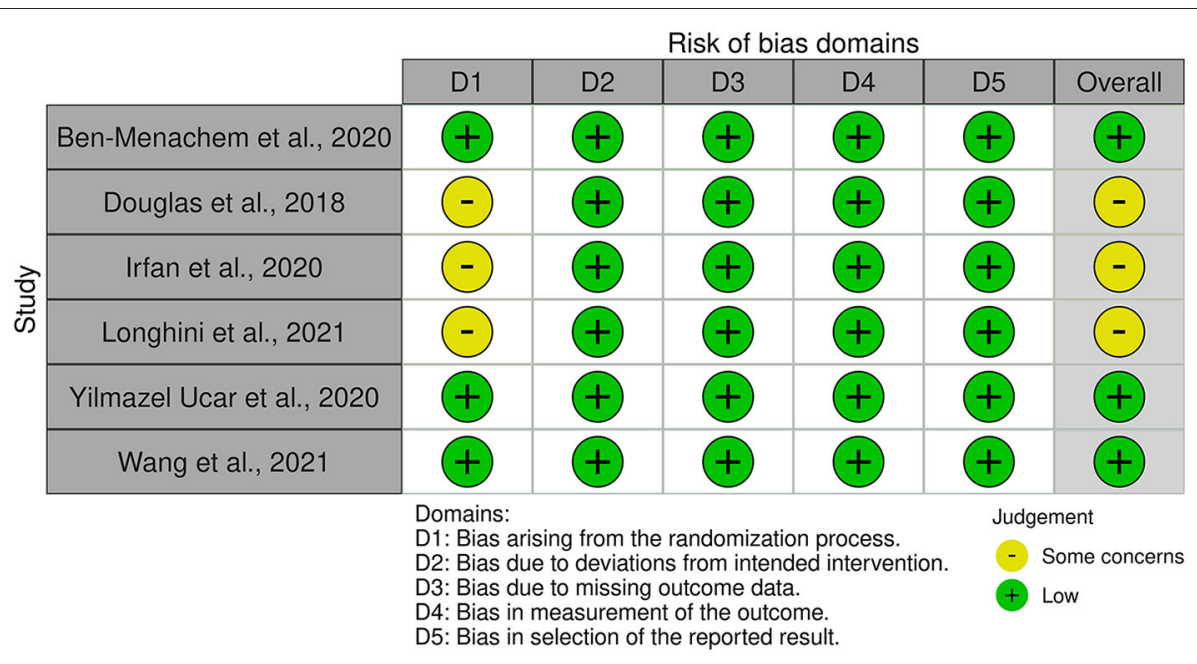

FIGURE 2 | Risk of bias for randomized control trials.

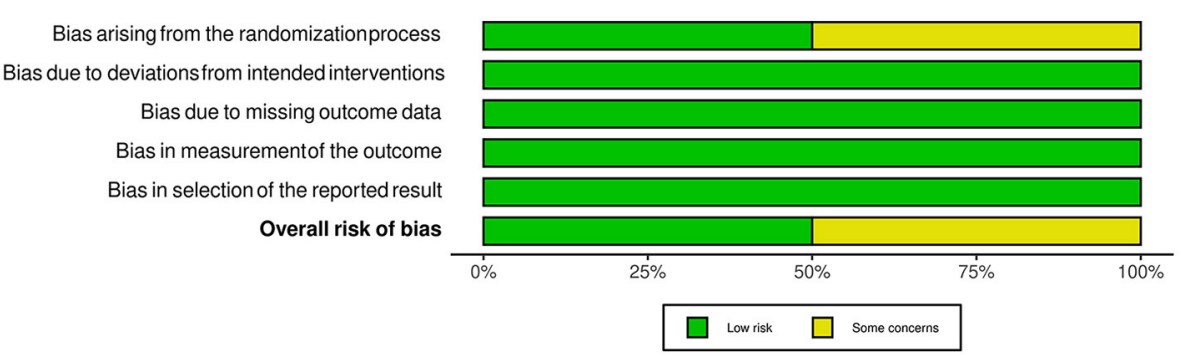

FIGURE 3 | Overall risk of bias for randomized control trials.

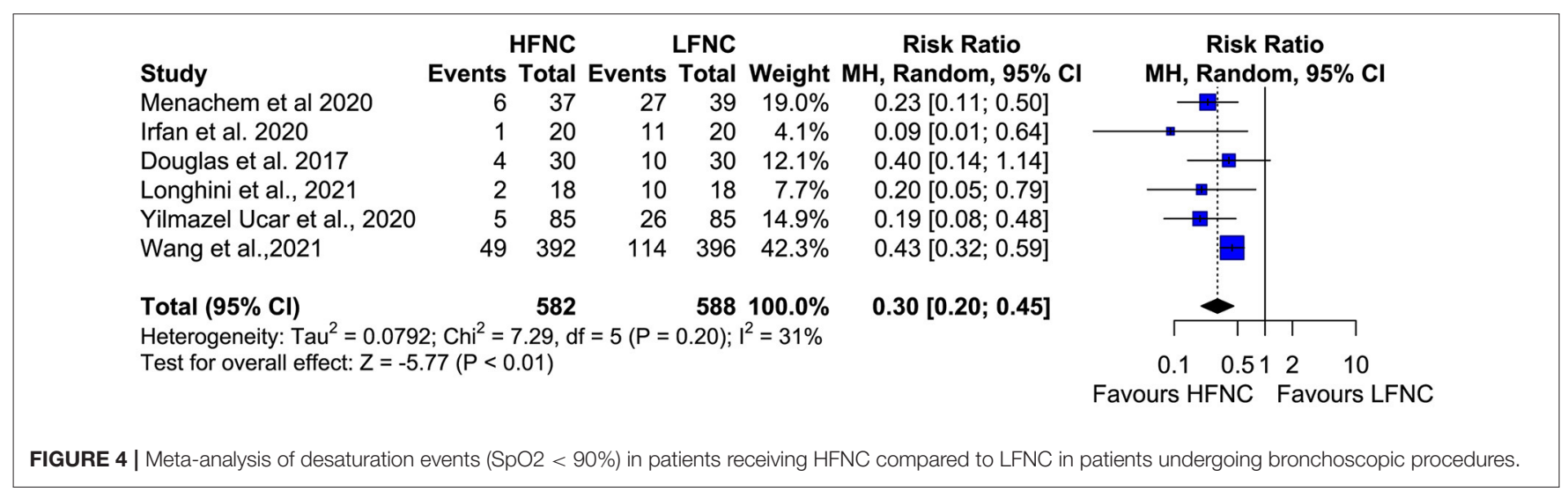

EBUS scopes have larger diameter and, with additional use of a balloon, can exert a greater negative effect on lung mechanics by increasing upper and lower airway resistance (18). HFNC can provide a CPAP effect on high-flow rates, humidification, and heating of inspired air, thus preventing alveolar collapse and lung de-recruitment while at the same time preserving lung compliance and upper airway patency, and washing out anatomic dead space by administering FiO2 up to 1. Therefore, it can protect from the development of hypoxemia during bronchoscopy procedures, most probably through preservation of normal lung mechanics $(3,5,6)$. Of note, in at least three of the included studies, the CPAP effect of HFNC could be hampered, since the oral route was the preferred one for bronchoscopy. Therefore, the beneficial CPAP effect of HFNC could be greater if the nasal route was used (20). None of these beneficial effects of HFNC can be provided by any other conventional oxygenation 


\begin{tabular}{|c|c|c|c|c|c|c|}
\hline Study & $\begin{array}{r}\text { HFNC } \\
\text { Mean SD }\end{array}$ & Total & $\begin{array}{r}\text { LFNC } \\
\text { Mean SD }\end{array}$ & & Weight & $\begin{array}{c}\text { Mean Difference } \\
\text { IV, Random, } 95 \% \text { CI }\end{array}$ \\
\hline Menachem et al 2020 & 94.35 .4 & 37 & 86.36 .9 & 39 & $18.8 \%$ & $8.00[5.22 ; 10.78]$ \\
\hline Irfan et al. 2020 & 97.53 .5 & 20 & 88.35 .0 & 20 & $19.2 \%$ & $9.20[6.53 ; 11.87]$ \\
\hline Douglas et al. 2017 & 96.83 .9 & 30 & 91.65 .4 & 30 & $20.4 \%$ & $5.20[2.82 ; 7.58]$ \\
\hline Longhini et al., 2021 & 95.02 .0 & 18 & 89.08 .0 & 18 & $14.8 \%$ & $6.00[2.19 ; 9.81]$ \\
\hline Wang et al.,2021 & 94.13 .2 & 392 & 90.53 .8 & 396 & $26.8 \%$ & $3.60[3.11 ; 4.09]$ \\
\hline otal $(95 \% \mathrm{Cl})$ & & 497 & & 503 & $100.0 \%$ & $6.18[4.01 ; 8.36]$ \\
\hline
\end{tabular}

Test for overall effect: $Z=5.58(P<0.01)$

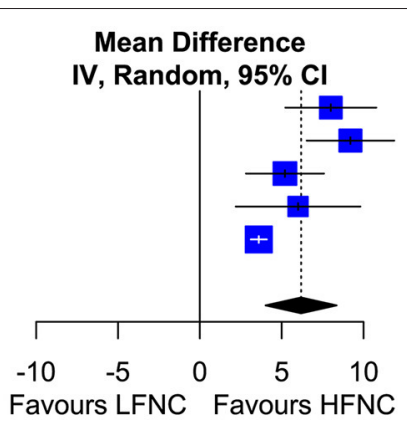

FIGURE 5 | Meta-analysis of lowest Sp02 in patients receiving HFNC compared to LFNC in patients undergoing bronchoscopic procedures.

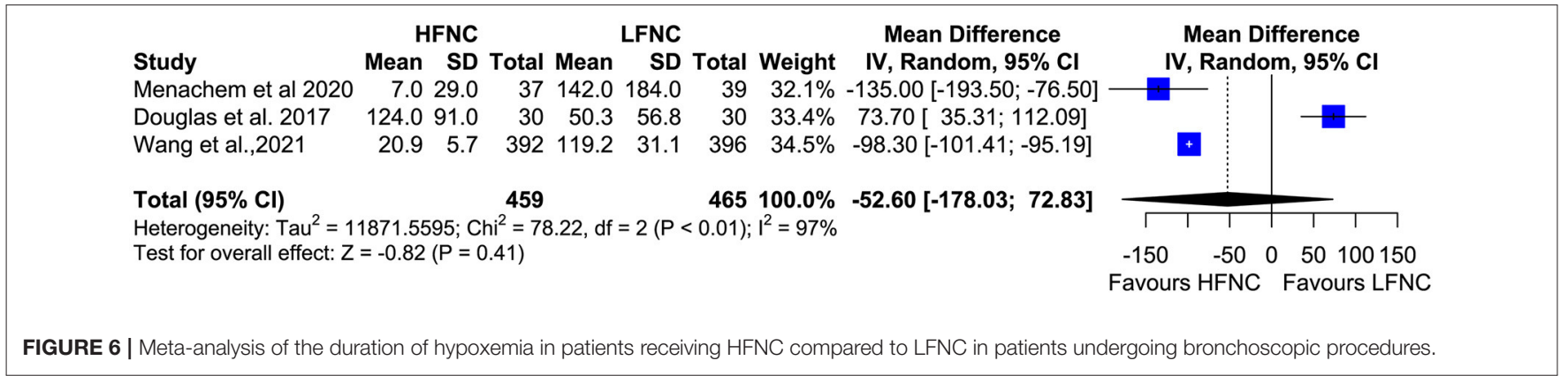

Study

Menachem et al 2020

Yilmazel Ucar et al., 2020

Wang et al.,2021

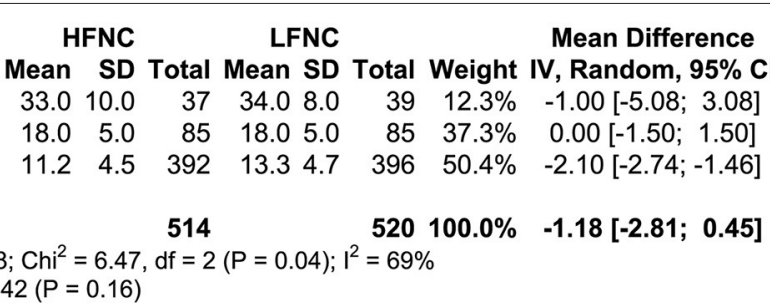

Heterogeneity: $\mathrm{Tau}^{2}=1.2638 ; \mathrm{Chi}^{2}=6.47$
Test for overall effect: $Z=-1.42(P=0.16)$

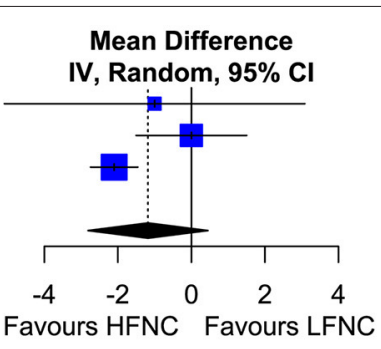

FIGURE 7 | Meta-analysis of the duration of procedure in patients receiving HFNC compared to LFNC in patients undergoing bronchoscopic procedures.

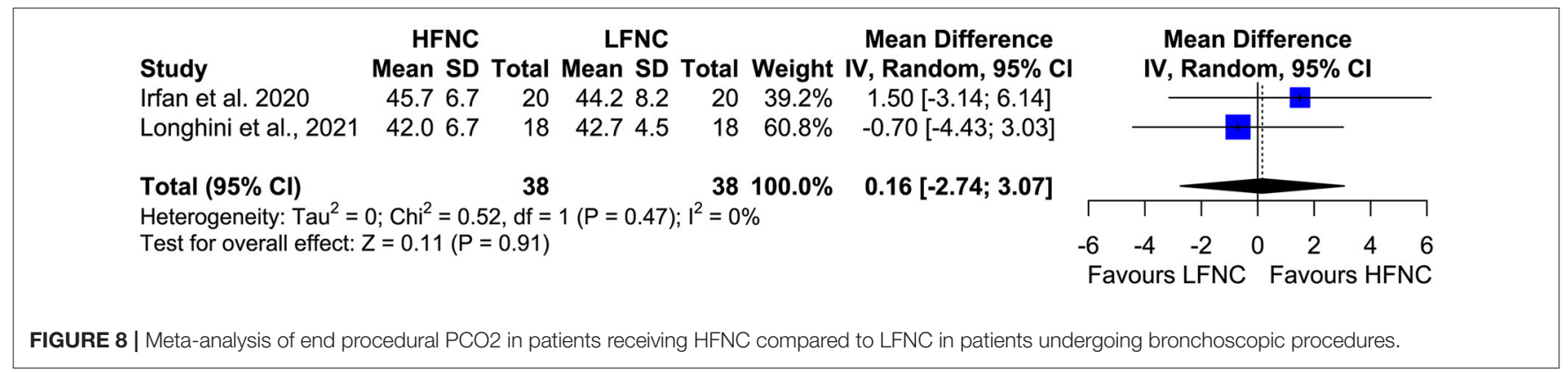

method, where FiO2 is highly variable and affected by the breathing pattern of a patient while the CPAP effect is absent $(3,22)$.

In the LFNC group, hypoxemic events were recorded in a surprisingly high rate of $33.6 \%$ of procedures compared to $11.5 \%$ in the HFNC group (Figure 3). Desaturations and minimum SpO2 during bronchoscopy can increase the risk of post-procedural events like supraventricular arrythmias and persistent hypoxemias $(7,23)$. The type of procedure (BAL, forceps/transbronchial biopsy, EBUS), age of patient, use and type of sedation, and position of patient during bronchoscopy are related to peri- and post-procedural hypoxemia and cardiac 


\begin{tabular}{|c|c|c|c|c|c|c|}
\hline Study & $\begin{array}{r}\text { HFNC } \\
\text { Mean SD }\end{array}$ & Total & $\begin{array}{r}\text { LFNC } \\
\text { Mean SD }\end{array}$ & & Weight & $\begin{array}{c}\text { Mean Difference } \\
\text { IV, Random, } 95 \% \text { C }\end{array}$ \\
\hline Yilmazel Ucar et al., 2020 & 94.02 .0 & 85 & 93.03 .0 & 85 & $20.7 \%$ & $1.00[0.23 ; 1.77]$ \\
\hline Wang et al.,2021 & 94.72 .7 & 392 & 93.42 .9 & 396 & $79.3 \%$ & $1.30[0.91 ; 1.69]$ \\
\hline Total (95\% Cl) & & 477 & & 481 & $100.0 \%$ & $1.24[0.89 ; 1.59]$ \\
\hline
\end{tabular}

Test for overall effect: $Z=6.96(P<0.01)$

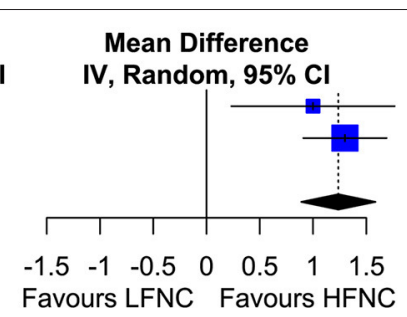

FIGURE 9 | Meta-analysis of SpO2 10 min after the end of the procedure in patients receiving HFNC compared to LFNC in patients undergoing bronchoscopic procedures.

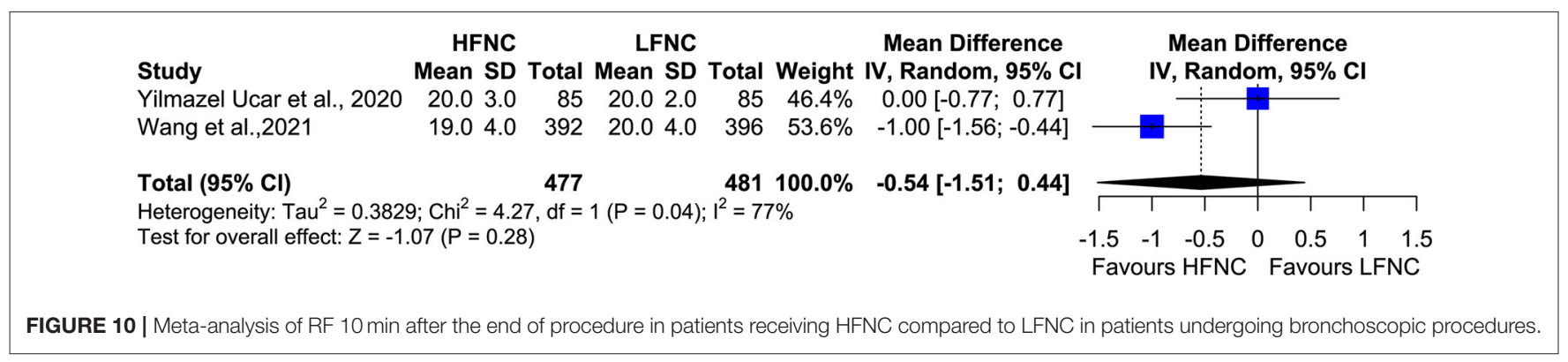

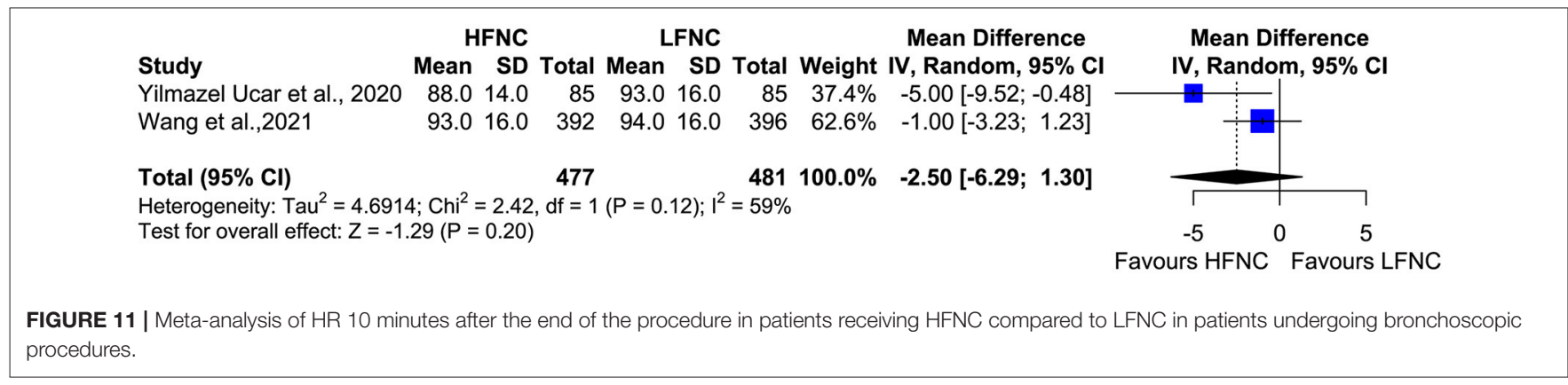

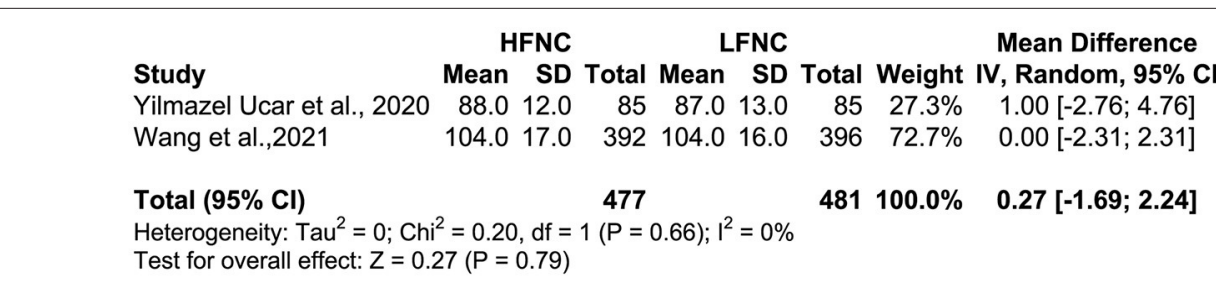

FIGURE 12 | Meta-analysis of MAP 10 min after the end of procedure in patients receiving HFNC compared to LFNC in patients undergoing bronchoscopic procedures.

arrythmias (7, 24). Cardiac complications, especially atrial and ventricular arrhythmias, are associated with minimum $\mathrm{SpO} 2$ value during the procedure and pose a great risk for post-procedural complications (25). Therefore, the utility and efficacy of oxygenation methods that can reduce peri- and post-procedural hypoxemia and related cardiac complications are of great importance. Indeed, our study showed that $\mathrm{SpO}_{2} 10$ min post bronchoscopy was significantly lower in the HFNC group, which means that the patients under HFNC support recovered faster. Hypoxemia may persist for $2 \mathrm{~h}$ post bronchoscopy (26), and no study so far has examined the need for post bronchoscopy oxygen supplementation therapy (7). Therefore, the use of HFNC could reduce the need for post bronchoscopy oxygen supplementation therapy. No major differences were noted for HR, MAP, and RF.

Of note, in case of severe hypoxemia, the attending physician must access the airway, and in some cases reverse anesthesia and 


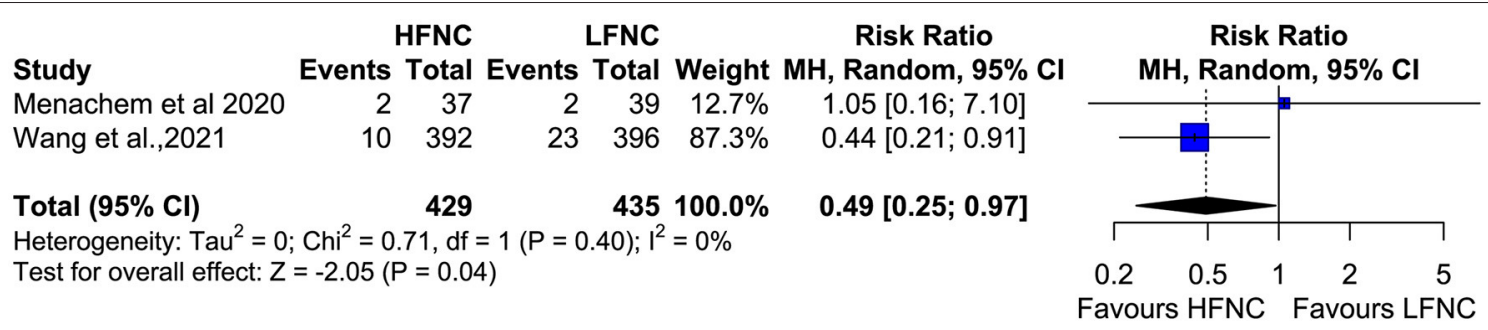

FIGURE 13 | Meta-analysis of the rates of pneumothorax in patients receiving HFNC compared to LFNC in patients undergoing bronchoscopic procedures.

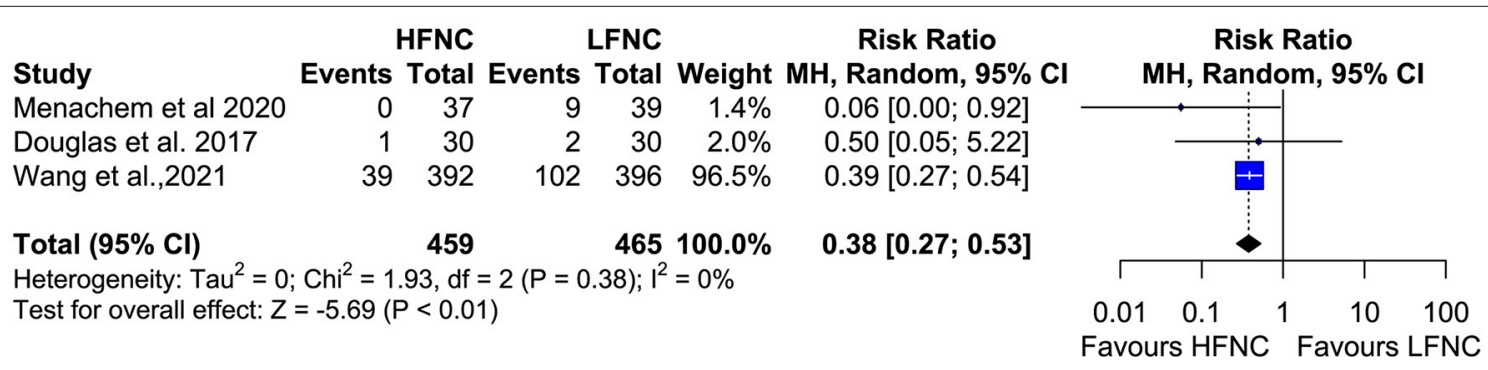

FIGURE 14 | Meta-analysis of procedural interuptions in patients receiving HFNC compared to LFNC in patients undergoing bronchoscopic procedures.

ventilate the patient to compensate hypoxemia and hypercarbia prolonging the duration of the procedure (23). Our study showed that procedural interruptions where indeed significantly less common in the HFNC group $(11,17,20)$, and that the duration of both bronchoscopy and hypoxemia (SpO2 < 90\%) and endprocedure $\mathrm{PCO}_{2}$ was longer in the LFNC group than in the HFNC group, but the differences were not significant $(11,16-$ 20).

With regard to major post-procedural complications, none of the studies reported any bronchoscopy-related intubations or deaths. This observation can be explained by the fact that most of the patients enrolled in the studies were outpatients or inpatients with no major comorbidities, such as concurrent respiratory failure. Development of severe respiratory failure requiring intubation and mechanical ventilation during bronchoscopy is less common in outpatients ( $<0.01 \%)$ (27, 28) than in inpatients. In the paper by Menachem et al. (17) authors reported higher satisfaction rates of the treating physicians in the HFNC group, evidence that reflects its beneficial effects. Pneumothorax incidence was reported in two studies $(17,20)$ with surprisingly significantly less events in the HFNC group. Even if HFNC administration has a limited CPAP effect, its application is related to increased respiratory support leading to less patient agitation, increased patient comfort, and, subsequently, better cooperation and shorter bronchoscopy duration $(20,29)$. No viral or bacterial contaminations were recorded.

Our study has many strengths and limitations. According to our knowledge, it is the biggest meta-analysis in the research field of bronchoscopy-induced hypoxemia, because it included a significant number of patients. All the included studies are RCTs with low heterogeneity and are of high quality. One primary and 10 secondary clinically relevantend points were addressed. Our study included almost 5 times more patients compared to an analogous meta-analysis by $\mathrm{Su}$ et al. (30). Therefore it had greater statistical power to address more clinically relevant outcomes like pneumothoraxes, mean SpO2, and other significant cardiorespiratory parameters in post bronchoscopy recovery time that have not been addressed in previous analogous studies (30). At the same time, our study showed significantly more procedure interruptions in the LFNC group, evidence that the study of Chien-Ling Su et al. failed to show, most probably because of the limited number of included patients (257) (30). Pelaia et al., in a recent systematic review and meta-analysis (31) addressed the benefits of HFNC vs. LFNC vs. continuous positive airway pressure (CPAP) modalities. They showed that HFNC is superior to LFNC with regard to lowest SpO2 and number of hypoxemic events, and that CPAP is superior to HFNC in the same clinical parameters. Nevertheless, our study focused solely on the benefit of HFNC vs. LFNC in bronchoscopic procedures, examining a multitude of clinically relevant outcomes in a much larger sample size.

Nevertheless, the exclusion criteria of all the studies were quite stringent, and patients with major comorbidities were not included, potentially affecting the generalizability of the meta-analysis outcomes. Indeed, all the studies were performed in a non-ICU setting, and the patients that were selected represent the bulk of the out-and inpatient population that would need to undergo bronchoscopy for various clinically significant diagnostic reasons like cancer, interstitial lung diseases, and infections. These underlying clinical conditions may compromise patients' periprocedural respiratory function. Unfortunately, in 
this meta-analysis, we cannot infer what the effects of HFNC would be in patients with severe respiratory failure and other major comorbidities who undergo bronchoscopy, but we can safely assume the inadequacy of low-flow systems during advanced bronchoscopic procedures in fragile populations with concurrent respiratory failure. Hypoxemia during bronchoscopy is more common in patients undergoing BAL, receiving sedation with benzodiazepines, and in those with compromised lung function (PEFR $<60 \%$ and FEV1 $<1 \mathrm{~L})(32,33)$. Of note, $51 \%$ of patients with FEV $1<1,000 \mathrm{ml}$ and $93 \%$ of those with FEV1 < $500 \mathrm{ml}$ will develop hypoxemia during bronchoscopy (33). In recent real life studies $(24,34,35)$, older age $(>70)$, inpatient status, duration of procedure, lower baseline $\mathrm{SpO}$, obstructive sleep apnea syndrome (OSAS), EBUS procedures and deep sedation were associated with higher complication rates and required escalation of care. Therefore, we can hypothesize that the benefits of HFNC application would be maximized in similar populations. No clear data exists examining the increased financial cost associated with the procurement of HFNC devises and consumables vs. possible benefits for the use of HFNC during bronchoscopy in the general population. We can assume that this can be compensated by reduction in the need for hospitalization and escalation of care, i.e., higher rates of pneumothoraxes in the LFNC group (Figure 13). Nevertheless, the use of HFNC in patients with severe respiratory failure and at risk for intubation has been proven to be cost-effective and safe (36).

Another limitation of our study is the variability of the respiratory support in both study arms (HFNC and LFNC) with $\mathrm{s}$ to devices/modalities, flow and $\mathrm{FiO} 2$, and variability in bronchoscopy route (oral vs. nasal) that might affect the effect of CPAP. The anesthetists and/or the bronchoscopists changed FiO2 during the procedure to match the patients' needs. As a result, the received $\mathrm{FiO} 2$ during desaturation event was variable, and a subgroup analysis matching the $\mathrm{FiO} 2$ was not feasible (37). In the majority of the included RCTs, the oral route was used; therefore, the beneficial effect of HFNC could be greater if the nasal route was preferred. The study population in the trial by Ben-Menachem et al. (17) differed from that of the other trials. Sedatives or anesthetic agents varied among the trials, and

\section{REFERENCES}

1. Spicuzza L, Schisano M. High-flow nasal cannula oxygen therapy as an emerging option for respiratory failure: the present and the future. Ther Adv Chronic Dis. (2020) 11:2040622320920106. doi: 10.1177/20406223209 20106

2. Durey A, Kang S, Suh YJ, Han SB, Kim AJ. Application of high-flow nasal cannula to heterogeneous condition in the emergency department. Am J Emerg Med. (2017) 35:1199-201. doi: 10.1016/j.ajem.2017.02.028

3. Mauri T, Wang YM, Dalla Corte F, Corcione N, Spinelli E, Pesenti A. Nasal high flow: physiology, efficacy and safety in the acute care setting, a narrative review. Open Access Emerg Med. (2019) 11:10920. doi: 10.2147/OAEM.S180197

4. Dysart K, Miller TL, Wolfson MR, Shaffer TH. Research in high flow therapy: mechanisms of action. Respir Med. (2009) 103:14005. doi: 10.1016/j.rmed.2009.04.007 sedation was not used in all the studies (Table 1). With regard to hard outcomes like intubation rates and deaths, these were reported in only two RCTs. Of note, another limitation of our study is that the favorable effect of HFNC in reducing the rates of pneumothoraxes and procedural interruptions are driven mainly by the study of Wang et al. (20).

Better designed and larger multicenter randomized control trials are sorely needed, including patient-centered outcomes such as complications requiring hospitalization, intubation rates, prolonged post-procedural hypoxemic events, cost effectiveness calculations, and inclusion of more representative subpopulations such as those with severe comorbidities who need to undergo bronchoscopy.

\section{CONCLUSION}

This meta-analysis highlights the potential superiority of HFNC to LFNC in reducing hypoxemic events and procedural interruptions during bronchoscopy. This potential protective effect of HFNC also extends to reduced rates of pneumothoraxes.

\section{DATA AVAILABILITY STATEMENT}

The raw data supporting the conclusions of this article will be made available by the authors, without undue reservation.

\section{AUTHOR CONTRIBUTIONS}

Data extraction was performed independently by two authors (FS and VK) while two authors (TK and AT) examined the two data sets for discrepancies. The rest of the authors provided expert insight for the physiology and the pathophysiology of NIV/high flow in bronchoscopies. GS provided insight for EBUS/bronchoscopies and their utility. All authors contributed to the article and approved the submitted version.

\section{FUNDING}

Publication of this manuscript was financed by the Research Committee of the University of Patras.

6. Mauri T, Alban L, Turrini C, Cambiaghi B, Carlesso E, Taccone P, et al. Optimum support by high-flow nasal cannula in acute hypoxemic respiratory failure: effects of increasing flow rates. Intensive Care Med. (2017) 43:145363. doi: 10.1007/s00134-017-4890-1

7. Du Rand IA, Blaikley J, Booton R, Chaudhuri N, Gupta V, Khalid $\mathrm{S}$, et al. British Thoracic Society guideline for diagnostic flexible bronchoscopy in adults: accredited by NICE. Thorax. (2013) 68 Suppl 1:i1-i44. doi: 10.1136/thoraxjnl-2013-203618

8. Vilmann P, Frost Clementsen P, Colella S, Siemsen M, De Leyn P, Dumonceau $\mathrm{JM}$, et al. Combined endobronchial and esophageal endosonography for the diagnosis and staging of lung cancer: European Society of Gastrointestinal Endoscopy (ESGE) Guideline, in cooperation with the European Respiratory Society (ERS) and the European Society of Thoracic 
Surgeons (ESTS). Eur J Cardiothorac Surg. (2015) 48:1-15. doi: 10.1093/ejcts/ ezv194

9. Dreher M, Ekkernkamp E, Storre JH, Kabitz HJ, Windisch W. Sedation during flexible bronchoscopy in patients with pre-existing respiratory failure: Midazolam versus Midazolam plus Alfentanil. Respiration. (2010) 79:30714. doi: 10.1159/000267227

10. Moher D, Liberati A, Tetzlaff J, Altman DG. Preferred reporting items for systematic reviews and meta-analyses: the PRISMA statement. PLoS Med. (2009) 6:e1000097. doi: 10.1371/journal.pmed.1000097

11. Douglas N, Ng I, Nazeem F, Lee K, Mezzavia P, Krieser R, et al. A randomised controlled trial comparing high-flow nasal oxygen with standard management for conscious sedation during bronchoscopy. Anaesthesia. (2018) 73:16976. doi: 10.1111/anae.14156

12. Sterne JAC, Savović J, Page MJ, Elbers RG, Blencowe NS, Boutron I, et al. RoB 2: a revised tool for assessing risk of bias in randomised trials. BMJ. (2019) 366:14898. doi: 10.1136/bmj.14898

13. McGuinness LA, Higgins JPT. Risk-of-bias VISualization (robvis): An R package and Shiny web app for visualizing risk-of-bias assessments. Res Synth Methods. (2021) 12:55-61. doi: 10.1002/jrsm.1411

14. Wan X, Wang W, Liu J, Tong T. Estimating the sample mean and standard deviation from the sample size, median, range and/or interquartile range. BMC Med Res Methodol. (2014) 14:135. doi: 10.1186/1471-2288-14-135

15. Luo D, Wan X, Liu J, Tong T. Optimally estimating the sample mean from the sample size, median, mid-range, and/or mid-quartile range. Stat Methods Med Res. (2018) 27:1785-805. doi: 10.1177/0962280216669183

16. Longhini F, Pelaia C, Garofalo E, Bruni A, Placida R, Iaquinta C, et al. High-flow nasal cannula oxygen therapy for outpatients undergoing flexible bronchoscopy: a randomised controlled trial. Thorax. (2021) 77:5864. doi: 10.1136/thoraxjnl-2021-217116

17. Ben-Menachem E, McKenzie J, O’Sullivan C, Havryk AP. High-flow nasal oxygen versus standard oxygen during flexible bronchoscopy in lung transplant patients: a randomized controlled trial. J Bronchology Interv Pulmonol. (2020) 27:259-65. doi: 10.1097/LBR.0000000000000670

18. Yilmazel Ucar E, Araz Ö, Kerget B, Akgun M, Saglam L. Comparison of High-Flow and Conventional Nasal Cannula Oxygen in Patients Undergoing Endobronchial Ultrasonography. Int Med J. (2020) 51:19359. doi: 10.1183/13993003.congress-2020.4413

19. Irfan M, Ahmed M, Breen D. Assessment of high flow nasal cannula oxygenation in endobronchial ultrasound bronchoscopy: a randomized controlled trial. J Bronchology Interv Pulmonol. (2021) 28:130-7. doi: 10.1097/LBR.0000000000000719

20. Wang R, Li HC, Li XY, Tang X, Chu HW, Yuan X, et al. Modified highflow nasal cannula oxygen therapy versus conventional oxygen therapy in patients undergoing bronchoscopy: a randomized clinical trial. BMC Pulm Med. (2021) 21:1-11. doi: 10.1186/s12890-021-01744-8

21. Matsushima Y, Jones RL, King EG, Moysa G, Alton JD. Alterations in pulmonary mechanics and gas exchange during routine fiberoptic bronchoscopy. Chest. (1984) 86:184-8. doi: 10.1378/chest.86.2.184

22. D'Cruz RF, Hart N, Kaltsakas G. High-flow therapy: physiological effects and clinical applications. Breathe (Sheff). (2020) 16:200224. doi: 10.1183/20734735.0224-2020

23. Mohan A, Madan K, Hadda V, Tiwari P, Mittal S, Guleria R, et al. Guidelines for diagnostic flexible bronchoscopy in adults: Joint Indian Chest Society/National College of chest physicians (I)/Indian association for bronchology recommendations. Lung India. (2019) 36:S37-89. doi: 10.4103/lungindia.lungindia_108_19

24. Eapen GA, Shah AM, Lei X, Jimenez CA, Morice RC, Yarmus L, et al. Complications, consequences, and practice patterns of endobronchial ultrasound-guided transbronchial needle aspiration: Results of the AQuIRE registry. Chest. (2013) 143:1044-53. doi: 10.1378/chest.12-0350

25. Katz AS, Michelson EL, Stawicki J, Holford FD. Cardiac arrhythmias. Frequency during fiberoptic bronchoscopy and correlation with hypoxemia. Arch Intern Med. (1981) 141:603-6. doi: 10.1001/archinte.141.5.603
26. Hendy MS, Bateman JR, Stableforth DE. The influence of transbronchial lung biopsy and bronchoalveolar lavage on arterial blood gas changes occurring in patients with diffuse interstitial lung disease. Br J Dis Chest. (1984) 78:3638. doi: 10.1016/0007-0971(84)90169-4

27. Facciolongo N, Patelli M, Gasparini S, Lazzari Agli L, Salio M, Simonassi C, et al. Incidence of complications in bronchoscopy. Monaldi Arch Chest Dis. (2009) 71:8-14. doi: 10.4081/monaldi.2009.370

28. Niwa $H$, Tanahashi $M$, Kondo $T$, Ohsaki $Y$, Okada Y, Sato S, et al. Bronchoscopy in Japan: a survey by the Japan Society for Respiratory Endoscopy in 2006. Respirology. (2009) 14:2829. doi: 10.1111/j.1440-1843.2008.01463.x

29. Tu G, He H, Yin K, Ju M, Zheng Y, Zhu D, et al. High-flow nasal cannula versus noninvasive ventilation for treatment of acute hypoxemic respiratory failure in renal transplant recipients. Transplant Proc. (2017) 49:1325-30. doi: 10.1016/j.transproceed.2017.03.088

30. Su CL, Chiang LL, Tam KW, Chen TT, Hu MC. High-flow nasal cannula for reducing hypoxemic events in patients undergoing bronchoscopy: a systematic review and meta-analysis of randomized trials. PLoS ONE. (2021) 16:e0260716. doi: 10.1371/journal.pone.0260716

31. Pelaia C, Bruni A, Garofalo E, Rovida S, Arrighi E, Cammarota G, et al. Oxygenation strategies during flexible bronchoscopy: a review of the literature. Respir Res. (2021) 22:253. doi: 10.1186/s12931-021-0 1846-1

32. Attaran D, Towhidi M, Toosi MAM. The relationship between peak expiratory flow rate before bronchoscopy and arterial oxygen desaturation during. Bronchoscopy. Acta Med Iran. (1970) 46:95-8.

33. Jones AM, O'Driscoll R. Do all patients require supplemental oxygen during flexible bronchoscopy? Chest. (2001) 119:19069. doi: 10.1378/chest.119.6.1906

34. May AM, Kazakov J, Strohl KP. Predictors of intraprocedural respiratory bronchoscopy complications. J Bronchol Int Pulmonol. (2020) 27:135141. doi: 10.1097/LBR.0000000000000619

35. Cho J, Choi SM, Park YS, Lee CH, Lee SM, Yoo CG, et al. Prediction of cardiopulmonary events using the STOP-Bang questionnaire in patients undergoing bronchoscopy with moderate sedation. Sci Rep. (2020) 10:14471. doi: 10.1038/s41598-020-71314-1

36. Eaton Turner E, Jenks M. Cost-effectiveness analysis of the use of high-flow oxygen through nasal cannula in intensive care units in NHS England. Expert Rev Pharmacoecon Outcomes Res. (2018) 18:3317. doi: 10.1080/14737167.2018.1411804

37. Li J, Scott JB, Lee JH. Defining the optimal role of high-flow nasal cannula in pediatric procedural sedation. Pediatr Pulmonol. (2020) 55:32257. doi: $10.1002 /$ ppul.25105

Conflict of Interest: The authors declare that the research was conducted in the absence of any commercial or financial relationships that could be construed as a potential conflict of interest.

Publisher's Note: All claims expressed in this article are solely those of the authors and do not necessarily represent those of their affiliated organizations, or those of the publisher, the editors and the reviewers. Any product that may be evaluated in this article, or claim that may be made by its manufacturer, is not guaranteed or endorsed by the publisher.

Copyright (c) 2022 Sampsonas, Karamouzos, Karampitsakos, Papaioannou, Katsaras, Lagadinou, Zarkadi, Malakounidou, Velissaris, Stratakos and Tzouvelekis. This is an open-access article distributed under the terms of the Creative Commons Attribution License (CC BY). The use, distribution or reproduction in other forums is permitted, provided the original author(s) and the copyright owner(s) are credited and that the original publication in this journal is cited, in accordance with accepted academic practice. No use, distribution or reproduction is permitted which does not comply with these terms. 